\title{
The Struggle to Define a Nation
}

Rethinking Religious Nationalism in the Contemporary Islamic World

\author{
Edited by \\ Marco Demichelis \\ Paolo Maggiolini
}

Gorgias

2017 
Gorgias Press LLC, 954 River Road, Piscataway, NJ, 08854, USA

www.gorgiaspress.com

Copyright (C) 2017 by Gorgias Press LLC

All rights reserved under International and Pan-American Copyright Conventions. No part of this publication may be reproduced, stored in a retrieval system or transmitted in any form or by any means, electronic, mechanical, photocopying, recording, scanning or otherwise without the prior written permission of Gorgias Press LLC.

$\circ$

9

ISBN 978-1-4632-0642-0

Library of Congress Cataloging-in-Publication Data

A Cataloging-in-Publication Record is Available from the Library of Congress.

Printed in the United States of America 


\section{TABLE OF CONTENTS}

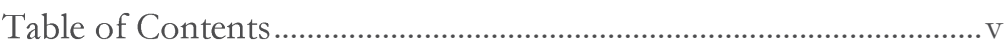

About the Contributors.........................................................................vii

Introduction. The Struggle to Define a Nation: Rethinking

Religious Nationalism in the Contemporary Islamic World ....1

MARCO DEMICHELIS AND PAOLO MAGGIOLINI

1. Religious Nationalism in the Official Culture of Multi-

Confessional Lebanon

ALEXANDER D. M. HENLEY

2. Syria's Lebanonization: An Historical Excursus within the

'Non-Existence' of Syrian National Identity................................45

MARCO DEMICHELIS

3. Nation-Narrating Monarchies: The Religious 'Soft Power' of

the Moroccan and Jordan Kings ......................................................75

MENNO PREUSCHAFT

4. Saudi National Identity: Historical and Ideational

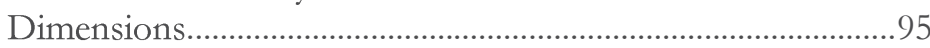

ELENA MAESTRI

5. Religion and Nationalism: Palestinian Christians and

Religious Leadership in the Midst of the Israeli-Palestinian

Conflict.

PAOLO MAGgIOLINI

6. 'Under the Same Flag': The Copts of Egypt and the challenges of Nasserist Nationalism.

ALESSIA MELCANGI

7. The Loner Desperado: Oppression, Nationalism and Islam in

Occupied Palestine.

ILAN PAPPE

8. Self-Sacrifice and Forgiveness: Religion and Nationalism in

the New Israeli and Palestinian Cinema ....................................221

YAEL BEN-ZVI MORAD 
9. Religion and Nation Building in Turkey: The Role of Institutionalized Religion in the Case of Diyanet. .251 GÜL ŞEN

10. Jundallah and Radical Religious Nationalism .277 FATEMEH SHAYAN

11. Nationalism and Islamism as Opposing Determinants of Iranian National Identity 311 ALAM SALEH

12. Evolving Face of Pakistan's Religious Nationalism 341 RAJA MUHAMMAD ALI SALEEM

13. The Limits of Secular Nationalism: Revisiting the Politics of Islam and National Identity in Bangladesh HUMAYUN KABIR

14. The Broken Mirror: How the Contemporary Jihadist Narrative is Re-Shaping the Classical Doctrine of Jihad........409 RICCARDO REDAELLI

15. Emerging Trends in the Broader Jihadi Galaxy: Between Radicalization and New Models of Jihadism. 439 ANDREA PLEBANI

16. Conclusion 1: From the Nahda to Nowhere? .469 PAOLO BRANCA

17. Conclusion 2: Democracy, Nationalism and Religion in the Arab World.... 497

YOUSSEF M. CHOUEIRI 


\title{
2. SYRIA'S LEBANONIZATION: AN HISTORICAL EXCURSUS WITHIN THE 'NON-EXISTENCE' OF SYRIAN NATIONAL IDENTITY
}

\author{
MARCO DEMICHELIS ${ }^{1}$
}

\section{INTRODUCTION}

The failure of the 'Syrian Spring' is unfolding before the eyes of the world. An analysis of possible outcomes and final resolutions is currently impossible, but one can assume that the pre-2011 Syria will not exist in the future: too many deaths, too much indiscriminate killing, too many inter-religious struggles. The failure of this country - which has played a significant role in contemporary Arab history from the end of WWI to the decolonization process and through the Cold War and into its aftermath - is symptomatically related to an identity fiasco that is largely attributable to the political leadership of the al-Assad family, but also, more generally, to a previous inability to shape a national distinctiveness able to accommodate the country's varied religious and political peculiarities.

It is important to note the irony that Syria, which tried to control Lebanon since the 1970s, and promoted a divide et impera policy, triggering a long civil war, was to undergo a very similar process. The Lebanonization of Syria, however, has taken much longer to occur and is only partially attributable to external factors.

${ }^{1}$ Dr. Marco Demichelis is a Marie Curie Fellow in the History of Middle East and Islamic Studies within ICS at the University of Navarra. 
The main topic of this article, it constitutes an historical journey in which Syria's inability to build a true national identity emerges as symptomatic of a reluctance to feel part of an inclusive and pluralistic state.

In Islam and the State, ${ }^{2}$ Panayotis J. Vatikiotis discussed the abnormality and the weakness of Islam and its irreconcilability as a universal faith with a national identity. Such incompatibility persisted within the Ottoman Empire until its fall, as it attempted to combine different religious and national identities under an increasingly weak Sultanate. Istanbul's failure to maintain control over its widespread empire, more similar to that of an earlier Islamic era than a national country, was due to its inability to prevent a subtle form of cultural ${ }^{3}$ and economic ${ }^{4}$ colonialism that, throughout the nineteenth century, exacerbated the clash within the weakening empire's Millet system, particularly in relatively impoverished North Africa and the Balkans.

\section{SYRIA MORE THAN SYRIA}

The outbreak of WWI against the Triple Entente intensified the Committee of Union and Progress' (CUP) and the Ottoman Sultan's mobilization of Islamic symbols to encourage international help in protecting one of the last representations of sovereignty in the Islamic world. In November 1914, the Sultan (who also held

2 Panayotis J. Vatikiotis, Islam and the State, (London, 1987).

${ }^{3}$ Phillip C. Allen, 'Early Arab Nationalism and the Orthodox of Syria: A comparative approach to the sectarian environment', The Arab Studies Journal, 1 (1993), pp. 43-45; Fruma Zachs, 'Toward a protonationalist concept of Syria? Revising the American Presbyterian Missionaries in the nineteenth century Levant', Die Welt des Islam, New Series, 41 (2001), pp. 145-173.

4 The Berat was a commercial certificate given to religious minorities of the Ottoman Empire (Christian Armenians, Jews, Orthodox Christians, Maronites, Latin Patriarchate Christians, etc.) that gave them the opportunity to pay less trade customs duties and enjoy tax exemptions, making them richer than their fellow Muslims. James L. Gelvin, The Modern Middle East, (New York, 2008), tr. in Italian (Torino, 2009), p. 126. 
the title of caliph) issued a call to jihad to unite the Muslim community against the European aggressors. ${ }^{5}$

Despite CUP suspicions of the loyalty of some Ottoman Arab subjects, particularly those Christian cultural and political associations in Greater Syria with historic connections to European powers, there was an absence of any openly anti-government riots. This supports an historic argument that emphasized Syria's alliance with the Ottoman cause from the beginning. The CUP's headquarters was established in Damascus under the leadership of Jamal Pasha, who, however, knowing that some members of the urban intelligentsia were in direct contact with Great Britain and France, encouraged the repression. The hangings in 1915-1916 of an Arab senator, leading journalists, three Arab parliamentary deputies and members of some of the most distinguished families in Greater Syria, managed to arouse intense anti-CUP sentiments in the entire country, without, however, breaking the loyalty of the most important elements of the local Arab élite to the Ottoman Empire. If this historical understanding is undeniable, the foundation, in Paris, of the Jam'iyat al-'Arabiyya al-Fatat in 1909 or 1911, indicated that more than seventy members in Greater Syria were in deep disagreement with the majority of their coreligionists. ${ }^{6}$

Al-Fatat was the first pre-WWI organization to support the full independence of the Arab districts from the Ottoman Empire, as well as a Syrian platform of protest providing an opportunity to take part in a conversation with the Hashemite clan and the Arab revolt. Despite Antonius' assertion that, 'no other society had played as determining a part in the history of the national movement (as al-Fatat)' ${ }^{7}$ which is partially true concerning the role

5 William L. Cleveland, A history of Modern Middle East, (Boulder, 2004), p. 153.

${ }^{6}$ G. Antonious, The Arab Awakening, (London, 1938), p. 111; Dawn C. Ernest, From Ottomanism to Arabism: essays on the Origin of the Arab Nationalism, (Urbana, 1973), pp. 177-178; Russel Malcolm, The First Modern Arab state: Syria under Faysal 1918-1919, (Minneapolis, 1985), p. 72; James L. Gelvin, Divided Loyalties. Nationalism and Mass politcs in Syria at the close of empire, (Los Angeles, 1998), p. 55.

${ }^{7}$ G. Antonious, The Arab Awakening, p. 111. 
played by the organization in coordinating the first Arab Congress in Paris (1913), ${ }^{8}$ the results of the assembly were quite limited: a few statements about the use of Arabic and the creation of Arab militias in the different districts but not in war time. The Congress highlighted a real inability to understand the revolutionary historical phase that the Arab intelligentsia was beginning to undergo and was without any capacity to affect change. Such cultural associations, although motivated by the best intentions, represented only themselves and the increasingly nationalist attitude of an Arab cultural élite not particularly synchronized with the influence of the region's entrenched Arab urban notables:

Membership (in al-Fatat) was made subject to a long period of probation. Each recruit was introduced by one of the sworn members but was kept in ignorance of the identity of all the other members until he had been tried and proved, when he would be invited to take an oath to serve the ends of the society $[\ldots]$ For the first two years, its centre was Paris; and its membership remained small: then, its founders graduated and returned to their homes, it was shifted to Beirut in 1913 and in the following years to Damascus. Its membership rose to over 200, all of whom were Moslems, with but a few Christians. ${ }^{9}$

The Fatat's geographic resettlement in Syria stimulated its efficiency and contacts with the supporters of an Arab uprising but also its divisions. ${ }^{10}$ In May 1915, before the start of the revolt, Amir Faysal reached Damascus to encounter the leadership of al-Fatat and al- 'Ahd. On this occasion, both associations subscribed to the 'Damascus Protocol', a document that underlined the terms of

8 This was attended by reform-minded groups, such as the Jam'iyyat Beirut al-Islahiyya, led by Salim 'Ali Salam, the Arab League Society of Rashid Ridia, the 'Covenant Society', or al-'Ahd, the Literary Society of Istanbul and the League of Arab Patriots.

${ }^{9}$ G. Antonious, The Arab Awakening, p. 112.

${ }^{10}$ An important occurrence that transformed the organization, dividing it, with the mu'assisun (those who had joined Fatat before the end of WWI) outnumbered by the mubtasabun (new members), and increasing de facto internal divergence. 
agreement and Arab requests to the British, by which local secret organizations would offer their assistance to London's cause in the region. ${ }^{11}$

As reported by Robert J. and S. Hadawi, in The Palestinian Diary: Britain's involvement 1914-1945, the protocol recites:

The recognition by Great Britain of the independence of the Arab countries lying within the following frontiers: "North: The Line Mersin-Adana to parallel $37 \mathrm{~N}$ and thence along the line Birejek- Urga- Mardin- Kidiat- Jazirat (Ibn 'Unear)Amadia to the Persian frontier; East: The Persian frontier down to the Persian Gulf; South: The Indian Ocean (with the exclusion of Aden, whose status was to be maintained). West: The Red Sea and the Mediterranean Sea back to Mersin. The abolition of all exceptional privileges granted to foreigners under the capitulations. The conclusion of a defensive alliance between Great Britain and the future independent Arab State. The grant of economic preference to Great Britain. ${ }^{12}$

A detailed geographical document devoid of the confusion usually attributed to the Hussein-McMahon Correspondence, the British response, 'the Declaration of the Seven' was, as reported by James L. Gelvin, a masterpiece of ambiguity. The British pledged complete and sovereign independence to the Arabian Peninsula, already free from Turkish control, and to the areas where the Arab revolt made an important contribution during the war, such as Damascus, which was officially occupied by the Arabs after the battle of Megiddo (1918). ${ }^{13}$

The geographical level of the debate during the war and after it is a topic too multifaceted to be addressed in this article, but it is important, nevertheless, to underline some limited aspects. There were at least two conflicting requirements - the Arab (reduced to the relationship between Britain and the Hashemite clan) and that

${ }^{11}$ Liora Lukits, 'The Antonius Paper and the Arab Awakening over fifty years on', Middle Eastern Studies 30 (1994), pp. 883-895.

12 S. Hadawi, J. Robert, The Palestinian Diary: Britain's involvement 1914-1945, (London, 2006), p. 35.

13 James L. Gelvin, Divided Loyalties, p. 155. 
of a Bilad al-Sham - to which a local Nationalist receptiveness would try to reconcile the concept of Greater Syria. ${ }^{14}$ However, if the first tentative steps were reflected in the artificial and dictated creation of two Hashemite kingdoms in Iraq and Transjordan, due to the failure in achieving the first option - an Arab state as described within the Damascus Protocol, above - the Greater Syria project failed too for different reasons and a shared responsibility: first of all, the French mandate system and the disunity of the Arab-Syrian élite. ${ }^{15}$

Al-Fatat, for example, was unable to preserve the organization due to family/clan interests within the post-conflict phase. The Bakri family, ${ }^{16}$ with the figure of Nasib, became strongly allied with the Hashemite in the region, while the 'Azm, a prominent Damascene family that played a significant role as wali under the Ottomans, rapidly increased their anti-Hijazi attitude and instead supported the French mandate system. During the war, the Syrian exiles in Egypt contributed to the idea of a Syrian singularity, a Syrianness, that dissuaded many of them from supporting the Arab Revolt and caused them to be considered real nationalists by their Egyptian colleagues. ${ }^{17}$ 'Abd al-Rahman al-Kayyali, former president of the Arab Club in Aleppo, in his texts and poems emphasized the Syrian collective responsibility for their own liberation, assuming a pro-Faysal attitude that nevertheless remained more focused on Syrian suffering during the war than on promoting a real struggle for unity.

In addition to the idea of complete Syrian independence in its natural boundaries ${ }^{18}$ with no protection and no mandate, as clearly

14 Akram Fouad Khater, Sources in the History of Modern Middle East, (Boston, 2004), p. 162.

${ }^{15}$ M. Provence, The Great Syria Revolt and the Rise of Arab Nationalism, (Austin, 2005), p. 5.

${ }^{16}$ James L. Gelvin, Divided Loyalties, p. 57; M. Provence, The Great Syrian Revolt, p. 42; Philip S. Khoury, Urban Notables and Arab Nationalism: the politics of Damascus 1860-1920, (Cambridge, 2003), p. 75.

${ }^{17}$ James L. Gelvin, Divided Loyalties, p. 154.

18 An independent Syria in its natural boundaries signified a Greater Syria that included the district of Antioch, Lebanon, all of Palestine and 
perceived by the King-Crane commission in 1919, the rise of a form of religious patriotism was clearly argued by the Metropolitan of the Eastern Syrian churches: 'I proclaimed a new religion above all others, it is the religion of Arab unity which gathers together the children of the nation regardless of their faith.' ${ }^{19}$ This emphasized attention to the adage: 'Religion belongs to God; the nation to all.' A Syrian religious, proto-nationalist attitude that encouraged building a political community that disregarded religious affiliation, promoted reciprocal harmony to prevent France from intervening in favour of and to protect the Christian minority, but after France's refusal to consider the King-Crane commission, an Islamization of political rhetoric and Kemalist propaganda, which called for Islamic unity and jihad against the Christian enemy, became more common.

This potentially explosive situation would break out following the end of WWI, weakening Arab demands.

\section{AN ELUSIVE IDENTITY UNDER THE FRENCH MANDATE AND THE FAILURE OF 'GREATER SYRIAN' IDEOLOGY}

France's responsibility in annihilating Syria's unitary ambitions is historically undoubted, as is the Syrian national independence movement's inability to achieve a high degree of unity, cohesion and organization. Local factions in Iraq, as in Palestine, began to break up the patriotic Greater Syria vision, also because in Damascus the leaders became embroiled in personal, clan and ideological disputes favouring the French intervention.

As reported by Philip S. Khoury in Urban Notables and Arab Nationalism, ${ }^{20}$ Syria's internal configuration was dominated in 1918 by three nationalist organizations: the Palestinian Arab Club, the

the Fertile Crescent (Iraq), which were considered integral parts of this project. The natural borders of this region were: the Mediterranean Sea, the Sinai Peninsula, the gulf of 'Aqaba, the Arabian deserts and the Zagros Mountains.

19 James L. Gelvin, Divided Loyalties, p. 181.

${ }^{20}$ Philip S. Khoury, Urban Notables, p. 80; 'Factionalism among Syrian Nationalists during the French Mandate', International Journal of Middle Eastern Studies, 13/4 (1981), p. 442. 
Syrian al-Fatat Arab Independence Party and the al-'Ahd association, led by Iraqi military officers; a simplified but clear assembly already divided into geographical areas, that was greatly impacted by the European Mandate system and Faysal's enthronement in Baghdad in 1921.

A paradigmatic event that preceded European fragmentation of the Near East was the creation of the party of Syrian Unity at the end of 1918. This party was subscribed to by the majority of Syrian nationalist activists who had lived in Cairo during the war and who promoted a stronger Greater Syrian ideology, maintaining frequent contact with the British rather than with the pan-Arabist and anti-imperialist associations named above. The party of Syrian Unity tried to coordinate all the activities of Syrian and Palestinian associations within the Near East, and it organized a SyrianPalestinian executive Congress in 1921, when Syria and Lebanon were already under French control and while Palestine was under Britain's within an artificial Kingdom of Transjordan.

Moreover, a first internal schism occurred in 1922 when Palestinian representatives decided to withdraw from the Congress for its lack of attention to the Palestinian cause and the increasing Hashemite relationship with Zionism, as well as some of the Syrian members even suggesting reaching an agreement with the Jewish nationalist movement led by Chaim Weizmann.

However, a deeper fragmentation occurred within the Congress, creating two main factions, the first led by the Lutfallah family ${ }^{21}$ and 'Abd al-Rahman Shahbandar, ${ }^{22}$ and the second guided by Shakib Arslan ${ }^{23}$ and the Istiqlal party.

21 A Lebanese family that emigrated to Cairo, becoming particularly wealthy as moneylenders during the Anglo-Egyptian military expeditions in Sudan. The founder of the family, Michel, purchased cotton plantations with the revenues, becoming one of the most important landowners in the country. Their descendants developed strong links with the Hashemite family as advisers and bankers, increasing their support for the Arab cause during the decade of WWI. Philip S. Khoury, 'Factionalism among Syrian Nationalists during the French Mandate', p. 445.

22 'Abd al-Rahman Shahbandar, a Syrian physician trained at the Medical School of the Syrian Protestant College in Beirut, was accused 
The opposition of these two internal claims to leadership was clearly seen in the former's relations with the Hashemites and commitment to the British, and the latter's deeper anti-FrancoBritish and more Islamic, religious affiliation. The Druze leader, Shakib Arslan, emphasized gaining a pro-German and Turkish nationalist support to boost the Arab movements in the territories with an emphasis on Islamic moral principles and divine law. Arslan also increased his support through active collaboration with Rashid Rida, ${ }^{24}$ Ihsan al-Jabiri, ${ }^{25}$ and the ultra-nationalist party of alIstiqlal, in which was emerging the figure of Shukri al-Quwatli (the first president of an independent Syria).

The clash with the Lutfallah-Shahbandar faction (more secular and deeply associated with British economic and political interests in the region) erupted when Rashid Rida became an outspoken critic of the Hashemites, who described as corrupt and incompetent and subtly fostering their own interests rather than those of the Arab nation. Rather than suggesting an agreement with Zionism, the Arslan faction felt totally devoted to the Palestinian cause, in part because al-Istiqlal's party was intimately connected with activists in the Nablus area, such as 'Izzat alDarwaza, one of the protagonists of the Arab Congress of Paris of 1913.

The positions became irreconcilable in 1924 when Sharif Hussain laid claim to the caliphate after the abolition of the same

during the war of supporting Arab emancipation from the Ottoman empire and was forced to flee to Egypt to avoid being sentenced to death for 'conspiracy'. He committed himself to the Hashemite cause and, returning to Damascus in 1919, became the official interpreter of Charles Crane. Khoury, 'Factionalism', p. 446.

${ }^{23}$ William L. Cleveland, Islam against the West: Shakib Arslan and the Nationalist campaign against the West, (Austin, 2011); Paolo Branca, Voci dell'Islam Moderno, il pensiero arabo musulmano fra rinnovamente e tradirione, (Genova, 1997), p. 121.

${ }^{24}$ Rashid Rida, Al-Khilafa aw al-Imama al-Užma, (Cairo, 1934), p. 57.

25 The Al-Jabiri family was one of the most important in Aleppo, with a role of religious and cultural leadership dating from the $18^{\text {th }}$ century. Ihsan became mayor of Aleppo in 1920. 
by the Turkish National Assembly. The demand did not receive unanimous consensus, increasing the fragmentation and the harshness of the debate. Local leaders in many Syrian towns like Damascus and Aleppo obtained considerable religious support, but the majority of the Arab, Islamic religious establishment argued that the demand was mistimed. Rashid Rida accused the Hashemites of not being religiously qualified, of having used the Arab Revolt for personal ambitions and failing to create a unified Arab country, while acquiring political rule with the support of the British, behaviour that clearly vitiated the caliphate demand. ${ }^{26}$

Moreover, the main reason behind this appeal was connected to the balance of power in the Arabian Peninsula, where 'Abd al'Aziz ibn Sa'ud was leading his Ikhwan (distinct from the Muslim Brotherhood) near the holy cities of Mecca and Medina to conquer, at the end of 1925, all of the Hijaz. Al-Sa'ud's victory increased the fragmentation of the Syrian political consensus, amplifying the contrast between pro and anti-Hashemite factions while the latter continued to lose support because of their intriguing and dishonest attitude.

On the eve of the Great Syrian Revolt of 1925 against the French, the internal fragmentation of the Syrian-Palestinian Congress and al-Fatat Arab Independence Party was chiefly inspired by pan-Arab and anti-British and anti-Hashemite sentiments. The historical understanding of the Great Revolt has over the past few decades shown a sharp contrast between those who actually assumed the honour and burden of military confrontation and those who, especially in the urban areas, were unable to support the efforts of the rural regions. As clearly emerged in Provence's text, ${ }^{27}$ the role played by the Druze and Bedouin population of the Jabal Hawran was prominent. ${ }^{28}$ The Druze, under the leadership of Isma'il al-Atrash, became in the second half of the $19^{\text {th }}$ century the reference point for all the habitants of the region - Muslim and Christian - who paid an

\footnotetext{
${ }^{26}$ Philip S. Khoury, 'Factionalism', p. 450.

${ }^{27}$ M. Provence, The Great Syria Revolt and the Rise of Arab Nationalism,

${ }^{28}$ Ibid., p. 33.
} p. 42. 
annual tribute (khawa) for protection. The commercial agreements with Damascus' cultural and political elite integrated the Hawran Druze fifty years earlier than other Syrian minorities like the 'Alawis and Isma'ilis. The Atrash consolidated a strong commercial relationship with the most important Maydani's families (residing in the Damascus district of Maydan) such as the Sukkar, the Bitar, the 'Aflaq and the Shuwayri. Finally, during WWI the Druze contributed to supporting the Arab Revolt and the British from 1917 and when Faysal's military forces entered the capital, alongside the Hashemite leader, there was also the Sultan al-Atrash.

The advent of the French mandate promoted a conflict in the rural areas in general, but in particular in the Jabal Hawran, due to the assimilationist attitude of the military officers who viewed Syrian rural society as requiring une mission civilisatrice. The successful French attempts to encourage the role of religious minorities in Syria and Lebanon, to increase internal fragmentation, but also to ensure minimum local support, failed in the Jabal Druze where the European military forces created a local council (majlis) of shuyukhs under their supervision. A paternalistic approach, a policy of public works based on corvée, in lieu of taxes and obligatory military conscription, aroused the opposition led by Sultan al-Atrash.

The Great Syrian revolt started as a Druze uprising against French ineptitude in a limited geographical area, south of Damascus, in which Druze, Muslims and Christians resisted together, rendering meaningless the historicized French protection of Oriental Christians in the region. ${ }^{29}$ Other factions only joined later, as Khoury notes:

Although popular discontent in Damascus and other towns was increasingly daily, as result of economic paralysis and renewed political repression, the People's Party (created in the same year as the Syrian-Palestinian Congress) had no plans at the time to launch an armed uprising against the French. It was only after Dr. Shahbandar and his comrades received strong indications that the Druze rebels were scoring military successes against the French army that the People's Party

${ }^{29}$ Ibid., p. 63. 
shifted its strategy from one of political mobilization for election in October to one full-scale rebellion. ${ }^{30}$

However, if, after an initial healing, a political and military partnership between the Druze and the Lutfallah-Shahbandar faction in the Syrian-Palestinian Congress was signed, at the outbreak of the Revolt, in 1925, the radical pan-Arabist group, led by the Arslan-Istiqlal coalition, was playing a more active role in the nationalist consensus of Syrian intelligentsia. This contingency would have weakened the impact of the Uprising, further fragmenting Syrian society.

The political failure of all the Syrian forces except the Druze showed the immaturity of the urbanized nationalist parties when, in 1926, the French army reorganized and was able to fight back. In November 1925, while the Druze insurrection was already being quelled, Shakib Arslan was publicly invited to France to resolve the Syrian problem and proposed a diplomatic agreement:

If France granted Syria independence, allowed the Alawite territory to become part of a unified country and permitted the Syrian district attached to Lebanon in 1920 to choose by plebiscite the state to which they wished to belong [...] then the nationalists would be willing to concede to France exclusive economic and strategic advantages in the country such as the right to issue loans, to train the Syrian army, to establish a naval base on the Syrian coast and conclude a mutual defence treaty. ${ }^{31}$

The proposal, implemented by the French to stall for time, created confusion, increasing the fragmentation within nationalist circles and enlarging the rift between the different groups supporting the

30 Philip S. Khoury, 'Factionalism', pp. 454-455; Syria and the French Mandate: the Politics of Arab Nationalism, 1920-1945, (Princeton, 2014); 'The Tribal Shaykh, French Tribal policy and the Nationalist movement in Syria between Two World Wars', Middle Eastern Studies, 18/2 (1982), pp. 184-185.

31 M. Provence, The Great Syria Revolt and the Rise of Arab Nationalism, p. 125; Philip S. Khoury, 'Factionalism', p. 456. 
revolt. Lutfallah attacked Arslan for having decided to keep the Syrian-Palestinian Congress in the dark while reaching a personal agreement to enhance his prestige. This split clarified the political inability of Syrian nationalists, as the Druze army remained ever more isolated and incapable of stopping the reorganized French army, particularly as a result of a lack of funding and of urban commercial support for the fighters in the Jabal Hawran. The equivocal behaviour of a part of the Damascus elite, such as the 'Azm and Jaza'iri clans, who were more interested in preserving their economic benefits with France than in really contributing to plan a strong insurrection in the capital (with the Druze forces not far from the city centre), decreased the opportunity of real success. ${ }^{2}$ The uprising involved few areas of the country and the contribution from some minorities like the Alawite and the Christians was limited; the Druze faced the French quite alone. ${ }^{33}$

The great revolt highlighted a lack of unity: the French policy of divide et impera had gone to reward different factions. In the 1930s - after the victory of Léon Blum's Popular Front coalition in the French elections of 1936 - representatives of both countries signed a draft treaty to provide an alliance between France and Syria and granted France responsibility for the defence of Syrian sovereignty and the right to maintain air bases and military garrisons on Syrian soil. However, Blum's leftist coalition unraveled in 1938 and the Franco-Syrian treaty was not ratified, plunging the country again under firm French control; only those Druze who had rebelled against Paris, re-established autonomy, together with the Alawite state on the Mediterranean coast. ${ }^{34}$

If, in Lebanon, the French mandate stimulated the establishment of religion-based politics, increasing the Maronites' aspirations for a geographical entity in which they were a relative majority, in Syria, on the contrary, the policy was to encourage the militarization of minorities (which also accentuated a more rapid process of internal secularization), the Alawite in particular, to

${ }^{32}$ M. Provence, The Great Syria Revolt and the Rise of Arab Nationalism, p. 100.

33 Ibid., p. 94.

34 William L. Cleveland, A history of Modern Middle East, pp. 224-225. 
destroy any sense of national unity. The Druze and Alawite identities, historically supported by 'religious diversity' and both expressions (for the Sunnis) of a spiritual deviation, and geographically rooted in rural areas, emphasized the differing ideas of a unified Syria: when Antun Sa'adeh implemented his vision of 'Greater Syria', establishing the Syrian Social Nationalist Party in 1934, the Lebanonization process in the area had already started and the idea of shaping an Arab country, geographically comprehensive of Palestine, Lebanon, Syria and northern Iraq, was completely unfeasible. ${ }^{35}$

At the end of the 1930s, the French parliament refused to ratify the treaties of 1936 as already reported above, with the additional aggravation of selling the district of Alexandretta to Turkey. ${ }^{36} \mathrm{~A}$ new insurrection exploded in a densely-populated Alawite area (with a Turkish minority of $38 \%$ ), but the repression was inexorable.

\section{NATIONALISM AND THE MUSLIM BROTHERHOOD, AN UNEXPECTED RELATIONSHIP}

The Syrian self-determination policy, successfully obtained with the end of WWII, did not generate a more substantial national unity than the previous one. Some old actors disappeared and a new nationalist bloc (al-Kutla al-Wataniyya) rebuilt the independence movement inside the country. As observed by Albert Hourani, with independence, the Syrian urban notables' system, more prone to bow to Ottoman or European authorities than to assume a more nationalist approach, were able to maintain a prominent social and political role. For the first time, veteran nationalists no longer had to put themselves forward as arbitrators between the Ottoman state or French mandate and local society; they were the rulers of their own country, while the age of the 'Azm and Jaza'iri clans was truly finished. The Politics of Notables was replaced by a politics of

35 Akram F. Khater, Sources in the History of Modern Middle East, p. 162.

36 Keith D. Watenpaugh, 'Creating Phantoms; Zaki al-Arsuzi, the Alexandretta Crisis and the formation of Modern Arab Nationalism in Syria', International Journal of Middle Eastern Studies, 28/3 (1996), p. 364. 
bureaucracies, ${ }^{37}$ but also by a more regional policy: a politics of the countryside against the new established urban elite. The Great Revolt of 1925 had already demonstrated that an insurrection without the military forces of the rural areas was impossible, but also, that without the financial support of the urban elite, any insurrection would be short-lived too.

In the post-colonial phase, the urban leadership would lose this recently gained power by failing to wed nationalism to state power, in highlighting a Syrian identity regardless of geography and religious identity. New political platforms (a national Syrian identity and a religious Syrian uniqueness) played an important role, but not within a real unification process; social and religious differences were preserved and stimulated. A growing middle class of students, teachers, mid-level military officers, small traders, moved mostly from rural areas to urban centres, demanded active inclusion in political decisions and destroyed the new equilibrium recently achieved with self-determination. Druze, Isma iilis and the Alawite in particular, redefined themselves, beginning to gravitate within new political organizations like the Syrian Communist Party, the Syrian Social Nationalist party and the Ba ${ }^{a}$ th. ${ }^{38}$

The political struggle clearly emerged in promoting internal clashes between those who attempted to preserve their positions and those who tried from outside to overthrow the government by the use of military force. To control the army became, decade after decade, a major goal for a compact minority like the 'Alawis: a dispossessed community (partially emigrated from the Alexandretta district after its inclusion in Turkey) with a heterodox brand of Islam and fiercely tribal, it played an increasingly important function within it. ${ }^{39}$ The French had encouraged them to join the

37 A. Hourani, 'Revolution in the Arab Middle East' in Revolution in the Middle East and Other Case Studies, Ed. P. J. Vatikiotis, (London, 1972), p. 71.

38 Philip S. Khoury, 'Continuity and Change in Syrian Political Life: the nineteenth and twentieth centuries', The American Historical Review, 96/5 (1991), p. 1393.

${ }^{39}$ Raymond A. Hinnebusch, Authoritarian Power and State Formation in Ba'ath Syria, (Boulder, 1990), p. 160. 
defence forces during the mandate, considering entry into the military as a means of social advancement. However, it would only be after independence that the 'Alawis began to penetrate the military in significant numbers, using their rural, regional and tribal solidarity to monopolize the highest levels of command. As reported by Hanna Batatu,

At first, they aligned themselves with rural Sunni Muslims in the armed forces to weaken Sunnis from the towns, who were in control of the army immediately after independence. Then the "Alawis turned on their rural Sunni allies and the smaller minority communities such as the Druzes. ${ }^{40}$

However, this increasing military and 'Alawis positioning in the country could have been avoided, if politicians had not fragmented themselves in the 40s and 50s, and instead had emphasized a rediscovered national unity.

A first mistake after independence was the centralizing policy: to reduce and abolish the communal representation in the parliament, in contrast with French policy during the mandate.

The pan-Arabist and ultra-nationalist idea, even if with limited Druze and Alawite intelligentsia support, was to destroy the centrifugal forces through military measures that increased the violence and the sense of unity in the country. The crushing of a new Druze revolt in $1954^{41}$ established the military primacy of the

${ }^{40}$ Hanna Batatu, 'Some Observations on the Social Roots of Syria's ruling military group and the causes of its dominance', Middle East Journal, 35/3 (1981), pp. 331-344.

41 The Druze revolt of 1954 erupted after independence, during a succession of Sunni-dominated governments that strove to centralize political authority, eroding Jabal's autonomy. The overwhelmingly Druze province of Suwayda, comprising the Jabal and its environs, was starved of development funds, while vast irrigation projects in other regions boosted agricultural production, driving down prices and impoverishing Druze farmers still further. The 'Atrash family was forced to rely on illicit drug cultivation to maintain its patronage networks. In addition, the quelling of the 1954 Druze revolt marked a turning point in the balance of power between the central government and the mountain dwelling 
Syrian Army, but also increased the subsequent political activism of these minorities, in addition to their urbanization, as already explained.

The second Syrian anomaly was connected to the inability to raise a political coalition able to maintain continuity not interrupted by military coups and external factors. The main coups (but not all) took place in 1949, 1951, 1954, 1961, 1963 and 1966, without a singular leader able to emerge as a real chief. Al-Kutla formed a solid bloc against the French, but after the treaty of 1936 and before independence was already splintered along regional and personal lines: the people's party of Aleppo with Rushdi al-Kikhiya and Nazim al-Qudsi revolted against the leadership of Sa'adallah alJabiri (a member of the previous Ottoman-Arab intelligentsia) while the Republican party of Jamil Mardam in Damascus broke off with Shukri al-Quwwatli. The author of the 1949 coup, 'Adib Shishakli, a Syrian of Kurdish origin and early member of the Syrian Social Nationalist Party, militarised the new government, promoting the idea that the country would be led by the armed forces, dissolving the party system and becoming the first autocratic figure without charisma. Finally, the internationalization of Syrian policy, which engaged with Pan-Arab feelings and defended the Palestinian cause, also increased the internal tension. ${ }^{42}$

The third error was the incomprehension which arose within the Ba'th (at the time, a still elitist party), between the Christian Michel 'Aflaq, the Sunnite Salah ad-Din Bitar and the Alawite Zaki al-Arsuzi. Professor Arsuzi's failure to preserve the Syrianess of the Alexandretta district and his move to Damascus - where, as an unemployed academic of philosophy and political thought, he became increasingly paranoid, irritable and depressed - unleashed an effective fragmentation within the party. In 1945, he received an

heterodox communities. The Druze's position against the military coup of Za'im and Shishakli was clear from the beginning. Moshe Ma'Oz, Avner Yaniv, Syrian Under Assad: Domestic Constraints and Regional Risks, (London, 2013), p. 22.

42 Moshe Ma'oz, 'Attempts at Creating a Political Community in Modern Syria’, Middle East Journal, 26/4 (1972), p. 398. 
offer to teach in Hama, he decided to quit political activism. ${ }^{43}$ Even if al-Arsuzi bowed out of the movement, an increasing part of its followers, rural Alawis, continued to play a significant role within the $\mathrm{Ba}^{\mathrm{c}}$ th, contributing, moreover, to a limited success: the Alawite Wahib al-Ghanim, during the parliamentary elections of 19471949, was defeated in the Lattakia district. We would have to wait until the early 1960s to see a renewed political interest of the Alawite community in Ba'th with the entrance of a reliable number of military officers.

Finally, the greatest error was the inability to increase political cooperation with the Syrian Muslim Brotherhood during the historical period after independence and before the 1970 Corrective Revolution exploded in the country, also adding further fragmenting religious identity. As reported by Joshua Teitelbaum, the Syrian Ikhwan was radically different from the Egyptian organization. If the Egyptian Muslim Brotherhood in the 1930s and 1950s was an extra-parliamentary movement, sometimes the perpetrator of violence and murders, in Syria, the organization was small, elitist, not engaged in supporting the Egyptian branch and, during the decade 1947-1958, a parliamentary body that witnessed the political turbulence of this historical phase. ${ }^{44}$ The importance and the wasted opportunity of working with the main Islamic organization before the advent of 'Political Islam', and prior to the oppressive Alawite policies against the Sunnis, revealed the Syrian case to be truly different from those of other Arab countries in which, from the beginning, the religious impact factor was predominant. In Syria, Sunni identity was important, but that of the minorities played a historical role clearly more permanent than that of the majority. The Brotherhood attended the 1947 parliamentary election as a normal political association: the Syrian Brotherhood did not found a national religious party but supported different

${ }^{43}$ Hanna Batatu, The Old Social classes and the Revolutionary movement in Iraq: a study of Iraq old landed and commercial classes and of its Communists, Ba'athists and Free Officers, (Princeton, 1978), p. 724.

44 Joshua Teitelbaum, 'The Muslim Brotherhood and the Struggle for Syria, 1947-1958 between Accommodation and Ideology', Middle Eastern Studies, $40 / 3$ (2004), p. 134. 
candidates in connection with local decisions. Three candidates of the Syrian Ikhwan obtained parliamentary seats, the first time within any Arab or Muslim country.

The Brotherhood's political activism, under the founder of the Syrian branch, Mustafa al-Siba'i, ${ }^{45}$ involved the association in the first Arab-Israeli war in 1948-1949, in which different units fought the Jihad until the end of the conflict. The Ikhwan afterwards supported, with the Ba'th and the People's Party, the increasing protests against the political ineptitude of government and Colonel Za'im's military coup against al-'Azm administration, still connected with the previous bureaucratic system of the mandate. ${ }^{46}$ The Brotherhood's policy to enforce democratic reforms was not well received by the colonel, who singled out the Communist Party and the Islamic movement, declaring them outlawed with all the rest of the Syrian party system in May 1949.

However, the increasing social activities of the Ikbwan, the foundation of a local newspaper, al-Manar al-Jadid, the formation of an Islamic Socialist Front, which emphasized the problem of corruption and the need for social equality (supporting progressive taxation, land reform, limitation of ownership and workers' rights, and also assuming a more pan-Arab attitude), was importantly summarized by Mustafa al-Siba'i:

We support all the Arab countries; we want the cancellation of artificial borders, and it is natural that we should begin with a union with Iraq. But we don't want such a union to constrain the free and independent state of Syria. In addition, we are firm in our support of the republican form of government. ${ }^{47}$

The post-1949 election, which led to the formation of a national assembly to draft a constitution, increased the impasse when the

45 Thomas Pierret, Religion and State in Syria. The Sunni Ulama from Coup to Revolution, (Cambridge, 2013), p. 36.

46 Joshua Teitelbaum, 'The Muslim Brotherhood and the Struggle for Syria, 1947-1958 between Accommodation and Ideology', pp. 138139.

47 Gordon H. Torrey, 'Syrian Politics and the Military 1945-1958', Journal of Modern History, $37 / 4$ (1965), p. 157. 
debate reached the topic of Islam as state religion of the country. Siba'i and his tone was above all quite pragmatic: he emphasized the importance of a national religion, mistakenly viewing the Israeli victory as rooted in a religious basis (while the secular platform of the first Israeli leadership is historically recorded), or arguing that the enshrining of Islam in the constitution would stimulate a greater attachment to the state. The draft constitution published in 1950 stated in Art. 3: 'Islam is the state religion; others' divine religions and religious minorities will be respected. There will be no discrimination between the citizens of the state on the basis of religion.' 48 This was more accommodating compared to the 1930 constitution that declared 'the religious head of Syria is Islam.' Nevertheless, in the subsequent discussion, the accepted formula returned to that of 1930 and in addition, the article included the statement that 'Islamic jurisprudence is the main source of legislation.' A step backward in relation to the previous version, in which religious equality was guaranteed by law.

In the early 1950s, even if the Ikhwan were showing a laudable political interaction within the Syrian party system, the Brotherhood had to deal with Shishakli's militarization and antireligious approach. In March 1952, the government issued a decree outlining standard clothing for the culama, and also prohibiting Muslims from sitting in coffee houses (presumably talking about politics) while wearing religious garments. In December 1952, Shishakli made his final move against his political opponents, claiming a 'plot' led by the Brotherhood, $B a^{6}$ th, the Arab Socialist Party and the Communist Party: the entire opposition. The elections of 1953 were boycotted and one year later, General Shawqat Shuqayr dissolved the parliament.

The apex of Syrian Ikhwan political maturity was reached in December 1955 when, on the anniversary of the hanging of six Egyptian Brotherhood members by 'Abd al-Nasser, the Syrian Brotherhood published an announcement in support of Egypt's foreign policy, but expressing its determination to condemn its internal policy against the Islamic association.

${ }^{48}$ Majid Khadduri, 'Constitution Development in Syria', Middle East Journal, 5 (1951), pp. 137-160. 
In conclusion, the fifteen years that followed independence showed an unstable political situation, due to an inability to create solid coalitions able to promote needed reforms, even though the Syrian Muslim Brotherhood confirmed an increasingly collaborative attitude, supported by a clear national identity interwoven with an Islamic religious dimension, the movement, in spite of this, was unable to convince the Syrian majority to adopt a form of universal Arab socialism in which the word 'Islamic' increased an apprehensive attitude. The majority of Syrian society was still pursuing a secular idea of national identity.

\section{THE ALAWITE LEADERSHIP AND RELIGIOUS CONFLICT WITH SUNNI ISLAM}

The basic insight of the Ba'th's two founders and ideologues Michel 'Aflaq and Salah ad-Din Bitar - was that a united Arab nation had been divided by imperialist intrusion and that being Arab did not mean being Muslim; Islam was one of the greatest creations of the Arab nation, but is not the soul of the nation Arabism is. ${ }^{49}$

Moving from an elitist party, imbued with Unitarian and socialist values, the $\mathrm{Ba}^{\mathrm{c}}$ th internally transformed itself in the decades following independence, assuming a less urbanized and intelligentsia-oriented profile, and increasing its rural support, especially among the middle-class farmers and landowners of the Alawi and Druze communities. As a consequence, the rurally based military officers gained access to a political organization and the $\mathrm{Ba}$ 'th was gradually transformed into a vehicle of their interests.

In particular after the failure of the United Arab Republic (UAR), the Ba'th retained its character as a nationalist middle-class movement; a previously nonexistent class-struggle ideology became more dominant, assuming a rural and military-civilian identity, both in relation to the influence played by Akram al-Hawrani within it, and to the historical period of the United Arab Republic, which showed that even without a proletarian revolution, the

${ }^{49}$ J. Galvani, 'Syria and the Baath party', Middle East Reports, 25 (1974), p. 5 
nationalization of industry and businesses, as well as land reform, could be realized.

The military coups of 1963 and 1966 involved the militarization of $\mathrm{Ba}^{\mathrm{c}}$ th and the internal separation between the National Command and the Syrian Regional Branch. The first coup, moreover, was intended to restore unity with Nasser's Egypt; the $\mathrm{Ba}^{6}$ th, however, remained sceptical of the opportunity.

Syrian national identity was again showing its failure to cohere: Syrian Arab Nationalists (pro-Nasserists) engaged in political conflict with a $\mathrm{Ba}^{\mathrm{c}}$ th party already divided itself between an older guard and a new military branch led by the Alawite Salah Jadid and Hafiz al-Assad. Additionally, the single-party system that the Ba'th was establishing did not obtain the support of al-Hawrani and his Syrian Communist Party or of the Muslim Brotherhood, which was increasingly aware of the secular drift of the country.

The majority of the Sunni Muslims were Arab Nationalists but not $\mathrm{Ba}^{\mathrm{c}}$ thist, while the party was chiefly dominated by minority groups like Alawites, Druzes, Christians and Ismailis, most of them from the countryside. However, the Neo-Ba'th coup of 1966 and the Corrective Revolution led by Hafiz al-Assad against Salah Jadid, was accepted without upheavals in the country. The year 1970 is the paradigmatic date in which the majority of Syrians, after decades of political setbacks, accepted the existence of an autarkic regime, militarized and led by the Alawite minority. ${ }^{50}$ The passage from an 'old romantic Ba'th party', still politically unable to win a democratic vote (in the 1963 elections, before the coup, the Ba'th had still obtained the electoral support of only $15 \%$ of voters), to the 'scientific socialist Arab way to Socialism', where the class struggle becomes predominant and the military's hierarchical role too, was stimulated, as stated above, by increasing factionalism after the UAR's failure and growing internationalist, leftist awareness.

50 Moshe Ma'oz, 'Attempts at Creating a Political Community in Modern Syria', p. 401; Amos Perlmutter, 'From Obscurity to Rule: The Syrian Army and the Ba'th party', The Western Political Quarterly, 22/4 (1969), p. 832. 
The original Syrian army was also decimated by coups and countercoups, leaving the Alawite officers to dominate first the high command, and then the entire state. In a decade, the Syrian Army emerged from the role of military force to become the political guardian of the country, and the ongoing secularization and radicalization of the forces increased the influence of a new generation of politicians, trained in the military structure. The army finally assumed the historical destiny of 'saving' society from the corruption of the politicians. ${ }^{51}$

However, there is an important characteristic that, as during the Great Revolt of 1925, clearly emerges: the predominant Alawite role in the army and the leadership of the al-Assad clan within a new Syria. Under the regime, the Syrian economy shifted from an agrarian base to an industrial-commercial sector, while oil (even if not abundant) replaced cotton as the main source of foreign revenue. The arrangement of public sector dominance and private sector participation gave Syria ten years of economic prosperity that increased approval for the new leadership, transforming the $\mathrm{Ba}$ th into a complementary political organ in which corruption and cronyism quickly appeared. Assad's foreign policy (in contrast with the previous decades in which Syria usually failed to appear as a leading country), thanks to greater internal stability, made Syria a regional power able to take independent decisions concerning Israel, Lebanon and international agreements. Finally, the Assad clan, like the Atrash family during the Great Revolt, emerged as the main actor in a society devoid of a true national identity, but rich in their minority and sectarian uniqueness.

In spite of this, Assad's most conspicuous predicament was the 1982 Hama massacre that branded his regime as a brutal, sectarian, Alawi dictatorship, murdering, suppressing and terrorizing many thousands of Sunni Muslims. ${ }^{52}$

51 A. Perlmutter, 'From Obscurity to Rule: The Syrian Army and the Ba'th party', p. 843.

52 P. Seale, Syria: The Struggle of Middle East, p. 326; William L. Cleveland, A History of Modern Middle East, p. 406; E. Rogan, The Arabs, (Italian version) p. 566; Th. Pierret, Religion and State in Syria, p. 188. 
The regime's inability to preserve at least a superficial concept of Unitarian awareness was already visible in the 1970s, when the new constitution of 1973 banned any religious reference to the country. In contrast with the constitution of 1950, which still referred to Syria as a country rooted on an Islamic base, article 8 of the new version, enshrined the quasi-single party system, supporting the idea that the $\mathrm{Ba}^{\mathrm{c}}$ th leads the state and society, without mentioning that the purpose of education is to raise 'generations of believers' and de facto banning outdoor Sunni religious celebrations.

This was a direct attack on Sunni religious identity. The apex was reached when Hafiz al-Assad also proposed to add to the constitution a statement that it is non-compulsory for the president to be a Muslim. The Ikbwan rebelled, but in this case, too, the internal positions were different: Sa'id Hawwa's ${ }^{53}$ petition, issued in Aleppo and subscribed to by the leading religious scholars, was considered too harsh by colleagues in Hama and Damascus, who decided to elaborate another text and to leave the final decision to Sheykh Habannaka, one of the leading religious figures at that time. In Homs, the same happened, and the local religious rulers wrote a third version of the petition; all of them were submitted to Habannaka who tried to moderate them but without great success. In the end, two of them were published in al-Hayat: the first described the authors of the constitution as enemies backed by colonialism, while the second called on Muslims to fight the partisan and sectarian domination. ${ }^{54}$ However, a few days before publication, on February 20, Hafiz al-Assad backtracked, asking parliament to accept the wishes of the nation and the majority of Syrian religious authorities.

The Hama uprising, in contrast to a more conciliatory approach in other Syrian urban areas, was symptomatic of the creation of an Islamic Front which, following an assassination attempt against Hafiz al-Assad, in June 1980, obtained the local support of the Muslim Brotherhood and the 'ulama. In November

${ }^{53}$ Itzchak Weismann, 'Sacid Hawwa and Islamic Revivalism in Ba'thist Syria', Studia Islamica, 85 (1997), pp. 131-154.

54 Th. Pierret, Religion and State in Syria, p. 187. 
of 1980, the Islamic Front, a militarized branch of the Ikbwan, which had staged a sporadic insurgency from 1976-1979 through a limited number of assassinations of prominent Alawi regime supporters, released a declaration of the Islamic revolution in Syria, which advocated the establishment of a relatively liberal Islamic state. ${ }^{55}$ However, as previously happened, the Front experienced tensions and divisions concerning its religious and political components, splitting the Muslim Brotherhood and the religious Sunni base (at the time more than $65 \%$ of the entire population) within the country.

Even in this case, the Alawite massacre against the Islamic Front in Hama froze an identitarian movement without improving the country's unity but clearly preserving its Lebanonization process. Hafiz al-Assad's subservient policy towards Iran during the $1980 \mathrm{~s}^{56}$ and the increasing pro-Shiite affiliation of Damascus within Lebanon ${ }^{57}$ further fractured the already limited national unity of the country, amplifying the Shiite-Sunni conflict.

Religion, after the Hama massacre, has therefore assumed a more symbolic sense of identity; this slaughter exacerbated a religious sense of belonging to internal communities, increasing national fragmentation and annihilating the plural and interreligious approach of the Syrian nationalist multi-party system of 1940s and 1950s. During the 1980s, as in the subsequent decades, to be a Christian identified you as a regime supporter, even if the individual person had never expressed this, and to be a Sunni a partial opponent. The process of sectarianism was intensified to obtain the unconditional support of all Syrian minorities, while the regime was acting, in an underground manner, to co-opt the support of part of the ulama, in particular in Damascus and Aleppo.

${ }^{55}$ Umar Abdallah, The Islamic Struggle in Syria, (Berkeley, 1983), pp. 128-187.

56 Yvette Talhamy, 'The Syrian Muslim Brothers and the Syrian Iranian Relationship', Middle East Journal, 63/4 (2009), pp. 561-580.

57 Asad Abukhalil, 'Syria and the Shiites: Al-Asad's policy in Lebanon', Third World Quarterly, 12/2 (1990), pp. 1-20. 


\section{CONCLUSION: THE DISAPPEARANCE OF SYRIA AND ITS MULTIPLE RELIGION UNIQUENESS}

The regime's nepotistic changeover, after the death of Hafiz alAssad in 2000, granted a fleeting illusion that a proto-democratic change could be possible. ${ }^{58}$ On the contrary, after the rapid failure of the 'Damascus Spring' in 2000-2001 and the 'Statements' of 99 and of 1000 , in which a culturally fomenting civil society tried to push the new leader towards a multi-party system, came the 'Winter' and the suppression of such movements again became the normal praxis.

Unexpectedly, Bashar al-Assad, showed his ability but also arrogance in revolutionising the country's political, economic and military leadership during the years after his father's death, ousting an old guard led by actors like Mustapha Talas and 'Abdul 'Alim Khaddam and bringing in a new intelligentsia like Shawkat Assad, Rami Makhlouf and Maher Assad (his younger brother), as reported by regime cronies and hidden sources. This radical internal changeover also weakened the Syrian autocracy, promoting internal divisions that reflected mistakes and superficiality such as that related to Kanaan Ghazi's suicide (in 2005), in direct connection with Rafiq Hariri's murder (in 2004) in Lebanon.

However, the failure of Syria's Arab Spring in 2011 gave confirmation to the basic assumptions that emerged in this article: the country's inability to build a national identity, the confirmation of deep internal religious divisions, the political inability to lead a multi-religious and multi-ethnic state and the Lebanonization of Syria as previously promoted by Damascus in the neighbouring country. The Alawite leadership has increased this attitude, preserving from this forma mentis only the economic elite, which partially remained multi-religious.

The existence of a Syrian elitist party-power, from the beginning of the $20^{\text {th }}$ century, is indicative of the fact that no ideological-political recipe has ever convinced the majority of Syrians, and even the Ba th, before the autarkic deviation of 1966,

58 Alan George, Syria, Neither Bread, nor Freedom, (London, 2003), p. 30. 
has never attained a relative majority. The interest in politics has remained connected with a clan and a familial elitism that has rarely brought the masses to manifest an active understanding.

This characteristic is probably attributable, on the one hand, to limited Syrian urbanization: until the end of WWII, only Damascus and Aleppo could be considered important urban areas. While, on the other, as reported by Philip S. Khoury in Urban Notables, is the long-lasting Ottoman system of urban elites that until the demise of the Sultanate played a deeply rooted role. As stated earlier, until Syrian independence in 1946, the old Ottoman primary form of control through families headed by the 'Ajlanis, Ghazzis, Kaylanis, 'Azms, Jaza'iris, etc. still survived, weakening any attempt to reform or rise against (as in the Great Revolt of 1925) the French mandate. When, after 1946, the Ottoman system rapidly collapsed, the pan-Syrian party system was unable to promote national unity, fragmenting the National Bloc and increasing the military's role: the only state authority linked to a non-Syrian background.

In addition, the presence of peculiar minorities like the Druze and the Alawi (which, under the Mandate, were endowed with great authority in a detached state and within the army) augmented their sense of national consciousness, which became particularly important with their urbanization process after independence. In other words: a cohesive new political system had not yet been created, so any balances were upset by a new minority of militarized elites.

Finally, Islamic revanchism and the Alawi's over-secular and pro-Shiite approach have amplified the Lebanonization of the country, rediscovering a religious identity that Islamic Sunni and Christian communities have strongly encouraged in recent decades, expressing conflicting worries. A sectarian religious nationalism made an eventual success of the Syrian Spring quite impossible, but must also be understood in relation to three relevant factors: the internationalization of the Sunni and Shi' a conflict from the 1980s, neighbouring Lebanon's civil war fragmentation and the absolutism of the Alawi nationalist secularization attitude. 


\section{BIBLIOGRAPHY}

Umar Abdallah, The Islamic Struggle in Syria, (Berkeley, 1983).

Asad Abukhalil, 'Syria and the Shiites: Al-'Asad's policy in Lebanon', Third World Quarterly, 12/2 (1990).

Phillip C. Allen, 'Early Arab Nationalism and the Orthodox of Syria: A comparative approach to the sectarian environment', The Arab Studies Journal, 1 (1993).

Akram Fouad Khater, Sources in the History of Modern Middle East, (Boston, 2004).

G. Antonious, The Arab Awakening, (London, 1938).

Hanna Batatu, The Old Social classes and the Revolutionary movement in Iraq: a study of Iraq old landed and commercial classes and of its Communists, Ba'athists and Free Officers, (Princeton, 1978).

_ 'Some Observations on the Social Roots of Syria's ruling military group and the causes of its dominance', Middle East Journal, 35/3 (1981).

William L. Cleveland, A history of Modern Middle East, (Boulder, 2004).

Dawn C. Ernest, From Ottomanism to Arabism: essays on the Origin of the Arab Nationalism, (Urbana, 1973).

J. Galvani, 'Syria and the Baath party', Middle East Reports, 25 (1974).

James L. Gelvin, The Modern Middle East, (New York, 2008), tr. in Italian (Torino, 2009).

, Divided Loyalties. Nationalism and Mass politcs in Syria at the close of empire, (Los Angeles, 1998).

Alan George, Syria. Neither Bread, nor Freedom, (London, 2003).

S. Hadawi, J. Robert, The Palestinian Diary: Britain's involvement 1914 1945, (London, 2006).

Raymond A. Hinnebusch, Authoritarian Power and State Formation in Ba'ath Syria, (Boulder, 1990).

Philip S. Khoury, Urban Notables and Arab Nationalism: the politics of Damascus 1860-1920, (Cambridge, 2003).

- Syria and the French Mandate: the Politics of Arab Nationalism, 1920-1945, (Princeton, 2014). 
-, 'The Tribal Shaykh, French Tribal policy and the Nationalist movement in Syria between Two World Wars', Middle Eastern Studies, 18/2 (1982).

—-, 'Factionalism among Syrian Nationalists during the French Mandate', International Journal of Middle Eastern Studies, 13/4 (1981).

-, 'Continuity and Change in Syrian Political Life: the nineteenth and twentieth centuries', The American Historical Review, 96/5 (1991).

Liora Lukits, 'The Antonius Paper and the Arab Awakening over fifty years on', Middle Eastern Studies 30 (1994).

Malcolm Russel, The First Modern Arab state: Syria under Faysal 19181919, (Minneapolis, 1985).

Moshe Ma'oz, 'Attempts at Creating a Political Community in Modern Syria', Middle East Journal, 26/4 (1972).

Amos Perlmutter, 'From Obscurity to Rule: The Syrian Army and the Ba'th party', The Western Political Quarterly, 22/4 (1969).

Thomas Pierret, Religion and State in Syria. The Sunni Ulama from Coup to Revolution, (Cambridge, 2013).

M. Provence, The Great Syria Revolt and the Rise of Arab Nationalism, (Austin, 2005).

Yvette Talhamy, 'The Syrian Muslim Brothers and the Syrian Iranian Relationship', Middle East Journal, 63/4 (2009).

Joshua Teitelbaum, 'The Muslim Brotherhood and the Struggle for Syria, 1947-1958 between Accommodation and Ideology', Middle Eastern Studies, 40/3 (2004).

Gordon H. Torrey, 'Syrian Politics and the Military 1945-1958', Journal of Modern History, 37/4 (1965).

Panayotis J. Vatikiotis, Islam and the State, (London, 1987).

Keith D. Watenpaugh, 'Creating Phantoms; Zaki al-Arsuzi, the Alexandretta Crisis and the formation of Modern Arab Nationalism in Syria', International Journal of Middle Eastern Studies, 28/3 (1996).

Fruma Zachs, 'Toward a proto-nationalist concept of Syria? Revising the American Presbyterian Missionaries in the 
nineteenth century Levant', Die Welt des Islam, New Series, 41 (2001). 